\title{
Non-destructive and Destructive Methods to Determine the Leaf Area of Zucchini
}

\author{
Adriano Bicioni Pacheco (Corresponding Author), Jéssica Garcia Nascimento, Larissa Brêtas \\ Moura, Tárcio Rocha Lopes, Sergio Nascimento Duarte, Rubens Duarte Coelho, Patricia \\ Angélica Alves Marques
}

Rua do Trabalho 611, Vila Independência, Piracicaba SP, 13418-220, Brazil.

E-mail: ad.bicionipacheco@gmail.com

Received: Jan. 21, 2020

doi:10.5296/jas.v8i3.16299
Accepted: Mar. 10, 2020 Published: Mar. 16, 2020

URL: https://doi.org/10.5296/jas.v8i3.16299

\begin{abstract}
Leaf area estimation is a very important indicator in studies related to plant anatomy, morphology and physiology, and in many cases, it is a fundamental criterion to understand plant response to input conditions. Although there are leaf area prediction models have been produced for some plant species, a leaf area estimation model has not yet been developed for the zucchini. The objective of this paper was to determine the leaf area based on destructive and non-destructive methods for zucchini. The accuracy of measurement methods was evaluated and compared to determinations of the leaf area by the scanning integration method (LICOR equipment LI 3100C), considered as standard procedure. Non-destructive methods consisted of digital photography and measurement of leaf dimensions (width and length) based on ImageJ software. The destructive methods used were a) leaf area integrator LI-3100C, b) determination of leaf mass and c) weighing of leaf discs punched from the leaves. According to statistical parameters that evaluate the performance of the analyzed methods: determination coefficient $\left(\mathrm{R}^{2}\right)$, Pearson ( $\mathrm{r}$ ) correlation coefficient, Willmott agreement index (d) and Camargo and Sentelhas performance index (c) the parameters presented values higher than 0.8820 , classifying the methods as very good, whereas the modeling efficiency index (NSE) and the percentage of bias (PBIAS) also classified the methods as very good $(0.87 \leqslant \mathrm{NSE} \leqslant 0.99 ;-4.80 \leqslant \mathrm{PBIAS} \leqslant 1.40)$, except the ImageJ method without correction (NSE=0.77; PBIAS = -22.70).
\end{abstract}

Keywords: Curcubita pepo L., biometry, digital image, multiple regression analysis

\section{Introduction}

The zucchini (Curcubita pepo L.) is a vegetable from the Cucurbitaceae family, originating from Mexico and northern Central America (Cardoso and Souza Neto, 2016) and along with 
melon, watermelon, and cucumber belong to the same family, representing about $20 \%$ of world vegetables production (Bianchini, 2013). In Brazil, it is among the 10 vegetables with the highest economic value and highest production, especially in the center and south of the country. Its cycle lasts from 45 to 80 days, and it can be cultivated in the field, both in summer and spring (Camargo, 1981; Lopes et al., 2017).

Among the cucurbits, the zucchini is of great economic importance, especially in the state of São Paulo, where the largest planting areas in Brazil are concentrated (Koch, 1995). According to the Agricultural Economics Institute (IEA, 2019), in 2017, São Paulo state produced $64,876 \mathrm{Mg}$ of zucchini, which represents a growth of $121 \%$ since 2006 . However, despite the economic importance and nutrition of the zucchini, studies involving its physiology and related parameters such as leaf area, which is a variable indicating the potential yield of agricultural crops, are still needed.

Leaf area estimation provides a basis for physiological studies related to vegetative growth, photosynthetic relationships and plant-atmosphere processes. Leaf area and weight are good indicators of plant growth, from which growth parameters can be estimated (Salazar et al., 2018). Understanding the growth and development of the zucchini helps in the implementation of management techniques for the high yield of its production.

Leaf area estimation can be performed using measuring instruments (destructive methods) or regression models (non-destructive methods), and the advantages are related to their applications (Francisco et al., 2014). According to Schwab et al. (2014), destructive methods have the disadvantage that they are not applicable in situations where the quantity of samples is limited and/or when other parameters of the experiment will be evaluated for a long period of time, which makes it impossible to destroy the experimental units plots for direct measurements of the leaf area. On the other hand, non-destructive methods can be used to track the growth and leaf expansion of the same plant until the end of the cycle, as well as being fast and accurate.

Different destructive methods: planimeter, weighing method, hand scanners and optical laser devices for example, were developed to determine the leaf area; however, these procedures require leaf extraction, thus compromising plant development.

In general, studies in which it is necessary to evaluate crop growth in controlled cultivation environments require samples obtained by destructive methods, but this type of sampling is not feasible when it is necessary to measure growth of the same leaf over time (Salazar et al., 2018). An alternative is the use of regression models in which area and leaf weight can be predicted by parameters that correlate well with the variables of interest, without the need for destructive sampling techniques.

Non-destructive methods as linear regression with leaf physical linear dimensions and use of imaging software, for example, provide time savings compared to destructive methods and may be less expensive. Additionally, the models allow researchers to determine the leaf area of plants with the least variability and error (Serdare and Demirsoy, 2006), during different stages of crop development. 
In this context, the present work aims to evaluate the performance of the destructive and non-destructive methods in the estimation of the leaf area of zucchini.

\section{Materials and Methods}

\subsection{Cultivation Conditions}

The work was carried out in a greenhouse and at the Department of Biosystems Engineering of the Luiz de Queiroz College of Agriculture/ University of São Paulo, Piracicaba, Brazil.

The zucchini plants Corona F1 hybrid were grown in a protected environment and packed in $8.2 \mathrm{dm}^{3}$ polyethylene pots using the commercial AgroLink ${ }^{\circledR}$ Biogrow Fiber/Standard compound substrate using $1.0 \times 0.5 \mathrm{~m}$ plant spacing. Fertigation management was daily with the use of Hoagland and Arnon (1950) nutrient solution under drip irrigation.

\subsection{Sampling and Processing of Leaves}

The leaves were collected at 62 days after transplanting the seedlings of zucchini, because it is the period with the largest leaf area of the crop, presenting the maximum diversity of leaves. The healthy leaves were collected from 32 plants, being 3 or 4 leaves per plant, with a total of 103 leaves analyzed. Collection was performed randomly throughout the plant in order to have greater diversity in leaf limb sizes. The wide variability of leaf size allows the existence of extreme values which, is important in the modeling and representativeness of the generated models.

The methods Leaf area determination methodologies were applied individually to each of the 103 leaves, initially the non-destructive and then the destructive methodologies were performed (Figure 1). The non-destructive methods consisted of digital photography (ImageJ) and the measurement of leaf main linear dimensions (width and length). The destructive methods used were the reading by the leaf area integrator LI-3100C, the determination of leaf mass and the weighing of discs collected in the leaves (Figure 1).

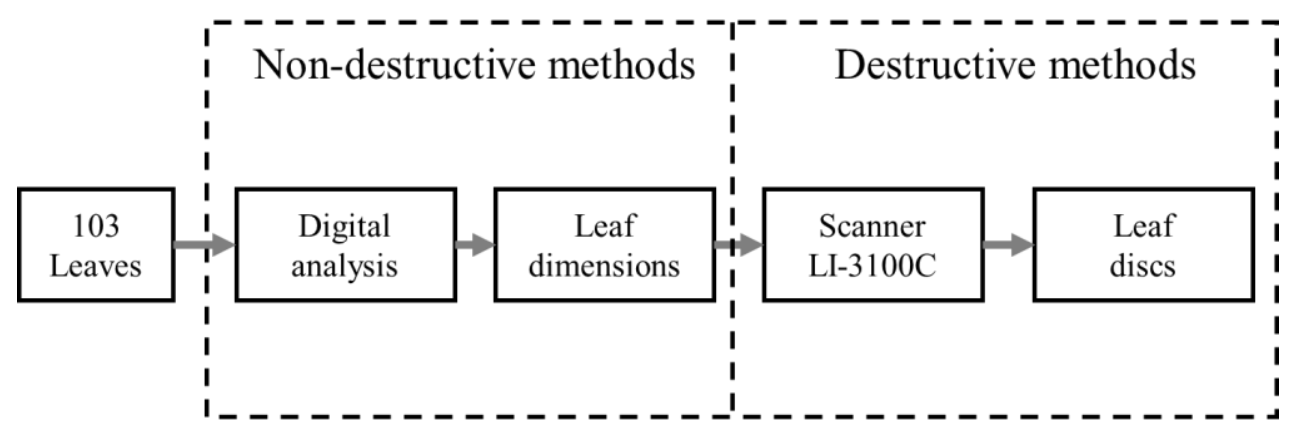

Figure 1. Flowchart with the order of leaf area determination processes by different methods.

\subsection{Leaf area by ImageJ Method}

For determination of leaf area with digital analysis, leaves were photographed under white background with a fixed scale of $10 \mathrm{~cm}$. The camera used was a Canon ${ }^{\circledR}$, model PowerShot SX170 IS. For the analysis, the free software ImageJ (Schindelin et al., 2015) was used. First the image was indexed to 8 bit, with 256 shades of gray to increase the contrast, and in 
sequence was performed on binary processing and recognition of the scale (Figure 2). Finally, the area was determined using the Measure tool from the Analyze menu.

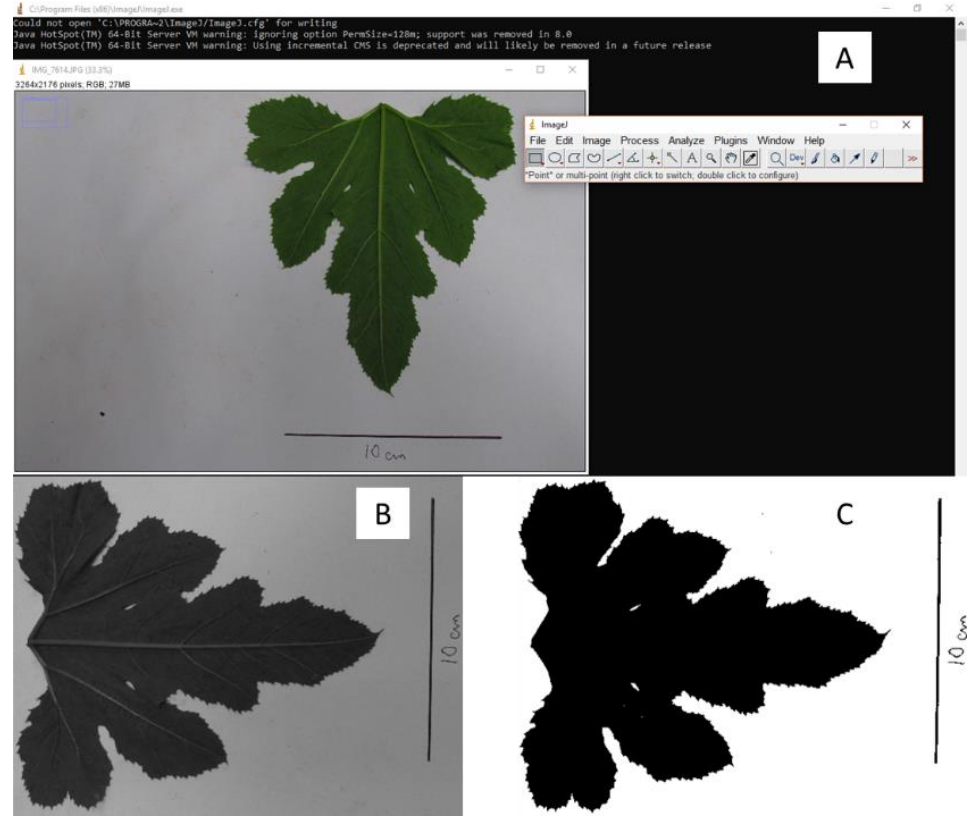

Figure 2. General layout and photo ImageJ image before treatment (A), sheet after indexing of 8-bit 256 gray shades (B) and after processing in binary (C)

However, the method by ImageJ was necessary to make a correction, due to errors related to the curvature of the camera lens, to avoid underestimation. The area was determined by the method with square images of known areas and a correction equation was determined (Figure 3). The method with the corrected data was named the corrected ImageJ.

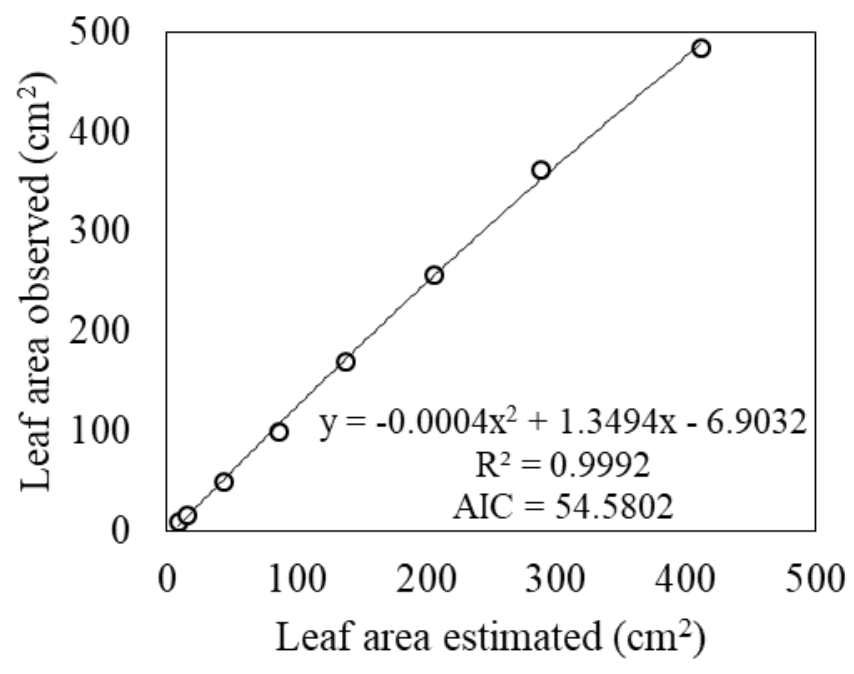

Figure 3. Equation for correction of ImageJ data; where: $y=$ actual area; $x=$ area estimated by ImageJ 


\section{Macrothink}

\subsection{Leaf Area by Biometric Variables of Zucchini Leaves}

The determination of leaf area based on the dimensions of the leaves, which are: a maximum width perpendicular to the central rib (L) and the length along the central web (W) leaves (Figure 4) was carried out with a precision ruler (millimeter).

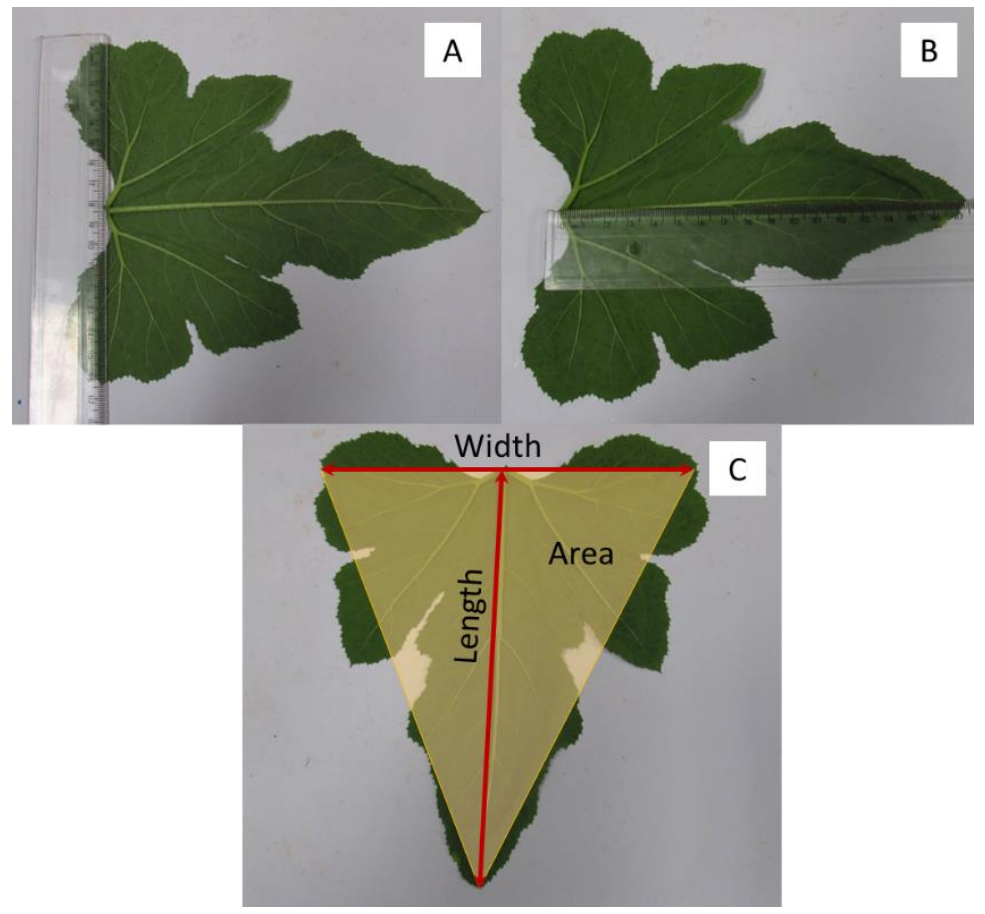

Figure 4. Determination of width (A) of the axial length of the sheet (B) and leaf area based on the circumscribed triangle $(\mathrm{C})$

The leaf dimensions were related to the leaf area obtained with the LI-3100C scanner through adjustments to multiple regression models and estimation of approximation coefficient to the area of a triangle (Figure 4C) with independent variables as leaf width ( W), the leaf length $(\mathrm{L})$, the leaf mass $(\mathrm{FW})$ and the product of the width and length $(\mathrm{L} \times \mathrm{W})$. The best fit models were selected by evaluating the CP Mallow statistic, the determination coefficient $\left(\mathrm{R}^{2}\right)$, the adjusted determination coefficient (Raj) and the Akaike Information Criterion (AIC) (Akaike, 1974).

\subsection{Leaf Area by Integrator LI-3100C}

The leaf area determination method considered as standard in the present study was leaf area integrator LI-3100C (LI-3100C, LI-COR, Lincoln, Nebraska, USA). The 103 leaves were placed separately in the equipment, and samples individual areas were obtained in $\mathrm{cm}^{2}$ (Figure 5). 


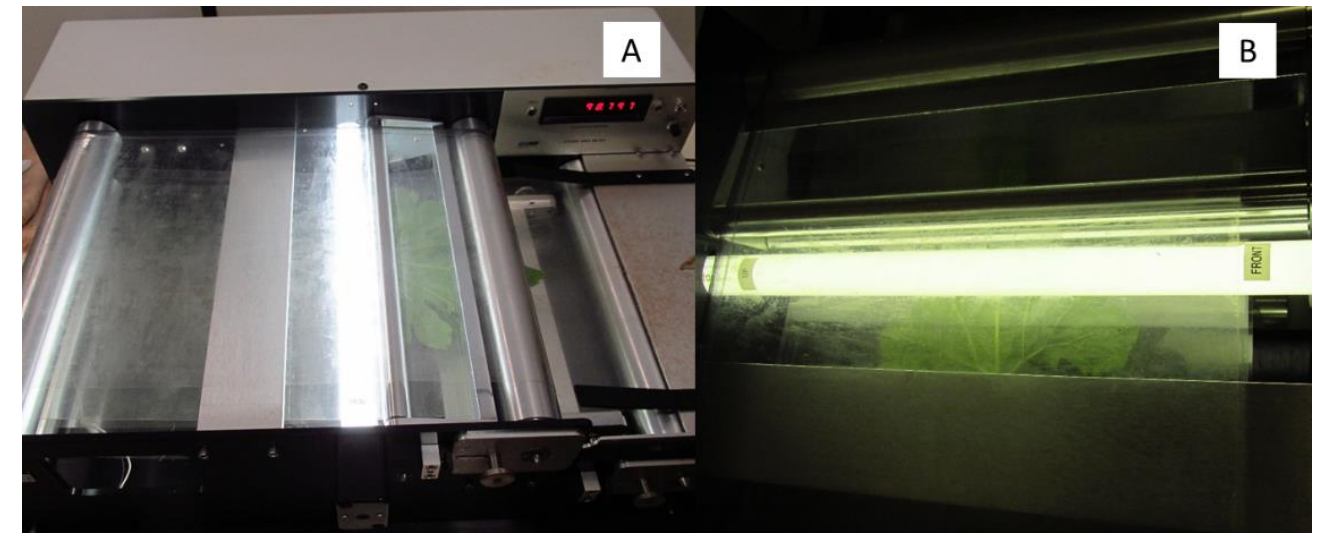

Figure 5. Leaf area measurement by the leaf area integrator LI-3100C (A) and detail of the leaf passage through the scanner (B).

\subsection{Leaf Area by Disc Method}

In the leaf disc method, two polyvinyl chloride (PVC) punction samplers with areas of 1.13 and $3.74 \mathrm{~cm}^{2}$ were used to collect samples along the leaf limb of small and large leaves, respectively. The number of discs ranged from six to ten, depending on the size of the analyzed leaf. Initially, the whole leaves were weighed and then the disks were sampled (Figure 6) and weighed on an analytical balance, accurate to $0.01 \mathrm{~g}$. Leaf area was estimated by Equation 1 (coming from the rule of three):

$$
\mathrm{AF}=\frac{\mathrm{MI} \times \mathrm{NC} \times \mathrm{AM}}{\mathrm{MC}}
$$

Eq. 1

Where: $\mathrm{FA}=$ estimated leaf area $\left(\mathrm{cm}^{2}\right) ; \mathrm{MI}=$ mass of whole leaf $(\mathrm{g}) ; \mathrm{NC}=$ number of circles taken from the sheet; $\mathrm{AM}=\mathrm{PVC}$ sampler area $\left(\mathrm{cm}^{2}\right)$; and $\mathrm{MC}=$ fresh mass of sampled circles $(\mathrm{g})$.

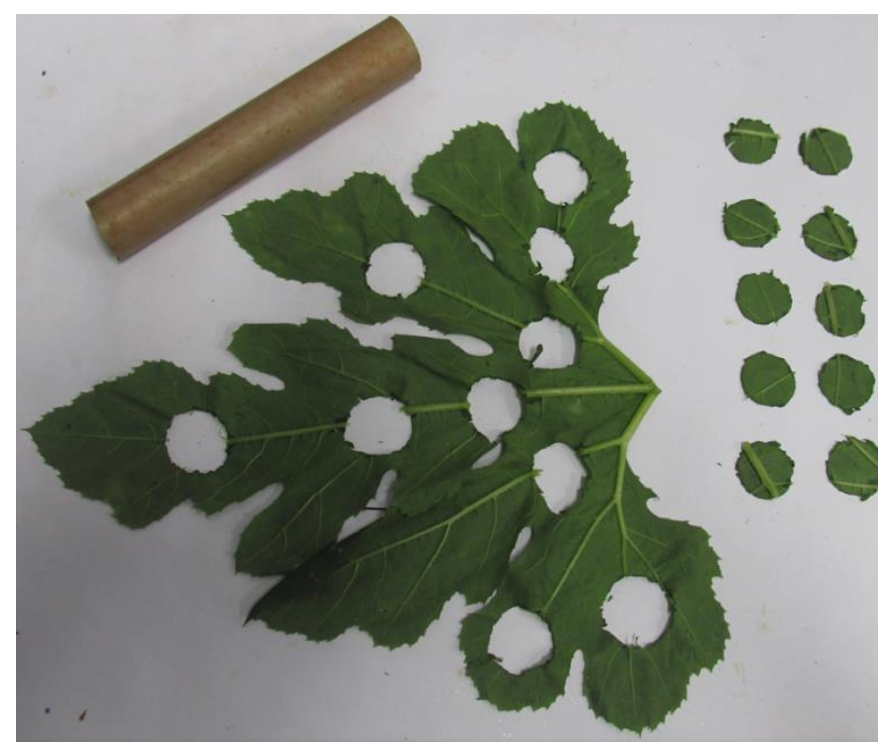

Figure 6. Sampling tool (PVC tube), leaf after sampling and leaf disc samples 


\section{1) Macrothink}

\subsection{Performance Indices}

The generated models and the direct methods to estimate the leaf area were evaluated for their performance by the following statistical indices and errors: Determination coefficient $\left(\mathrm{R}^{2}\right.$ ), Willmott Agreement Index (d) (Willmott, 1981), Confidence Index (c) (Camargo and Sentelhas, 1997), Mean Error (ME), Mean Absolute Error (MAE), Modeling Efficiency Index (NSE) (Nash and Sutcliffe, 1970) and Percent Bias (Yapo et al., 1996), determined by Equations 2, 3, 4, 5, 6, 7 and 8, respectively:

$$
\begin{aligned}
& R^{2}=\frac{\frac{1}{n} \times \sum_{i=1}^{n}\left[\left(E s t_{i}-\overline{O b s}\right) \times\left(\mathrm{Obs}_{i}-\overline{O b s}\right)\right]^{2}}{\left[\frac{1}{n} \times \sum_{i=1}^{n}\left(E^{2} t_{i}-\overline{E s t}\right)^{2}\right] \times\left[\frac{1}{n} \times \sum_{i=1}^{n}\left(\mathrm{Obs}_{i}-\overline{O b s}\right)^{2}\right]} \\
& \mathrm{d}=1-\frac{\sum_{\mathrm{i}=1}^{\mathrm{n}}\left(\mathrm{Est}_{\mathrm{i}}-\mathrm{Obs}_{\mathrm{i}}\right)^{2}}{\sum_{\mathrm{i}=1}^{\mathrm{n}}\left(\left|E s t_{\mathrm{i}}-\overline{\mathrm{Obs}}\right|+\left|\mathrm{Obs} \mathrm{s}_{\mathrm{i}}-\overline{\mathrm{Obs}}\right|\right)^{2}} \\
& \mathrm{C}=\sqrt{\mathrm{R}^{2} \mathrm{xd}} \\
& \mathrm{EM}=\frac{1}{\mathrm{n}} \mathrm{x} \sum_{\mathrm{i}=1}^{\mathrm{n}}\left(\mathrm{Est}_{\mathrm{i}}-\mathrm{Obs}_{\mathrm{i}}\right) \\
& \mathrm{MAE}=\frac{1}{\mathrm{n}} \mathrm{x} \sum_{\mathrm{i}=1}^{\mathrm{n}}\left(\left|\mathrm{Est}_{\mathrm{i}}-\mathrm{Obs}_{\mathrm{i}}\right|\right) \\
& \mathrm{NSE}=1-\frac{\sum_{\mathrm{i}=1}^{\mathrm{n}}\left(\mathrm{Est}_{\mathrm{i}}-\mathrm{Obs}_{\mathrm{i}}\right)^{2}}{\sum_{\mathrm{i}=1}^{\mathrm{n}}\left(\mathrm{Obs}_{\mathrm{i}}-\overline{\mathrm{Obs}}\right)^{2}} \\
& \text { PBIAS }=100 \times \frac{\left(\sum_{i=1}^{n} E_{s t_{i}}-\sum_{i=1}^{n} O b s_{i}\right)}{\sum_{i=1}^{n} O b s_{i}}
\end{aligned}
$$

Where: $\mathrm{R}^{2}$ - Coefficient of determination; $\mathrm{d}$ - Willmott Agreement Index, c - Confidence Index; MS - mean error; MAE - Mean absolute error; NSE - Modeling Efficiency Ratio; PBIAS - percentage bias; $\mathrm{n}$ - number of observations; Obsi - leaf area obtained by LI-3100C;

Esti - leaf area estimated by other methods; $\overline{\text { Obs }}$ - average leaf area obtained by LI-3100C;

$\overline{\text { Est }}$ - average leaf area estimated by the other methods.

The model classification according to its performance (very good, good, satisfactory and unsatisfactory) was based on the numerical evaluation table presented in Table 1. 
Table 1. Qualitative performance evaluation criteria for the statistical indices of leaf area determination methods (adapted from Moriasi et al., 2015)

\begin{tabular}{ccccc}
\hline \multirow{2}{*}{ Indices } & \multicolumn{4}{c}{ Statistical Evaluation Criteria } \\
\cline { 2 - 5 } & Very good & Good & Fair & Poor \\
\hline $\mathrm{R}^{2}$ & $>0,85$ & $0,75<\mathrm{R}^{2} \leq 0,85$ & $0,60<\mathrm{R}^{2} \leq 0,75$ & $\leq 0,60$ \\
$\mathrm{~d}$ & $>0,90$ & $0,85<\mathrm{d} \leq 0,90$ & $0,75<\mathrm{d}<0,85$ & $\mathrm{~d} \leq 0,75$ \\
$\mathrm{c}$ & $>0,84$ & $0,66<\mathrm{c} \leq 0,84$ & $0,61<\mathrm{c} \leq 0,66$ & $\mathrm{c} \leq 0,61$ \\
$\mathrm{NSE}$ & $>0,80$ & $0,70<\mathrm{NSE} \leq 0,80$ & $0,50<\mathrm{NSE} \leq 0,70$ & $\leq 0,50$ \\
PBIAS $(\%)$ & $< \pm 5$ & $\pm 5 \leq \mathrm{PBIAS} \leq \pm 10$ & $\pm 10 \leq \mathrm{PBIAS} \leq \pm 15$ & PBIAS $\geq \pm 15$ \\
\hline
\end{tabular}

\section{Results}

The modeling of leaf area estimation as a function of leaf dimensions (width and length) and mass was performed using multiple regressions, adopting Mallows' Cp statistics (Figure 7) and the coefficient of determination as the best selection criteria. $\left(\mathrm{R}^{2}\right)$ (Table 2). From the models defined by regression variables, the models $\mathrm{W}-\mathrm{WxL} ; \mathrm{W}-\mathrm{L}-\mathrm{FW}$; $\mathrm{L}-\mathrm{FW}-\mathrm{WxL}$; $\mathrm{W}-\mathrm{L}-\mathrm{FW}-\mathrm{WxL}$ and the circumscribed triangle because they have a lower value of AIC being these, $850.84,843.12,818.86,814.57$ and 850.12 , respectively (Table 2).

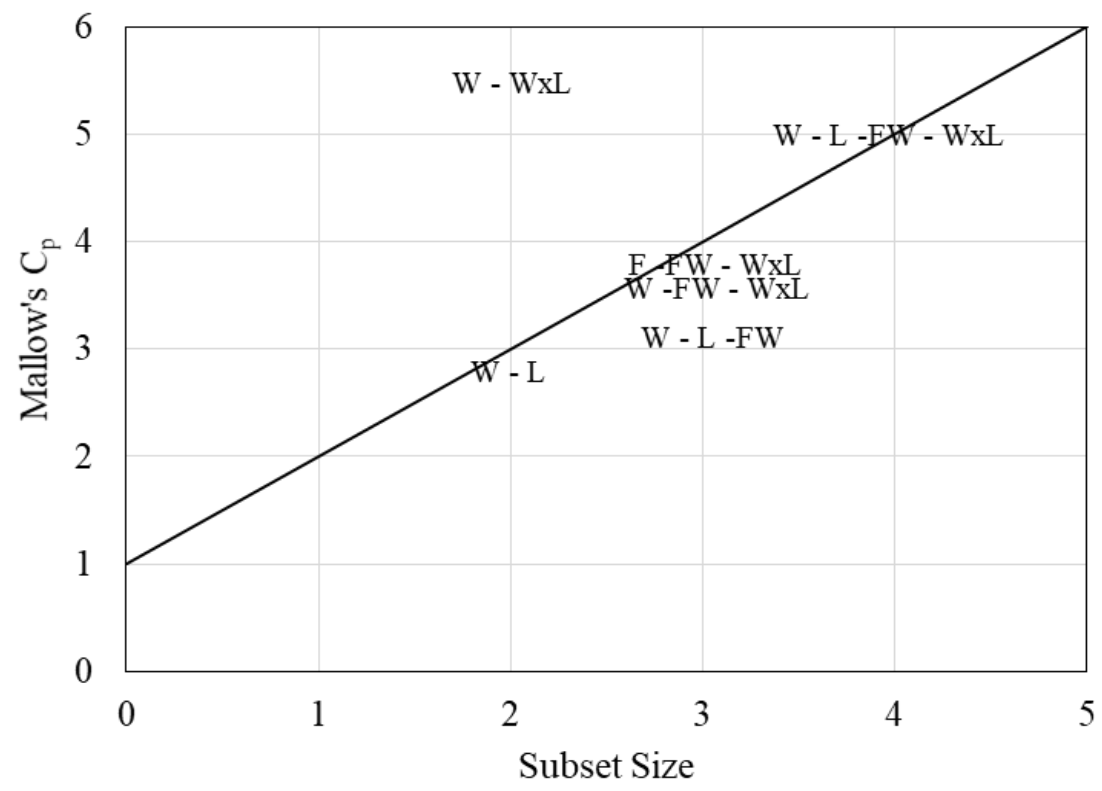

Figure 7. Selection of subsets of biometric variables of zucchini leaves by the Mallows' Cp statistics for leaf area modeling. Where: W - leaf width; L - leaf length; FW - the mass of the leaf; WxL - product of width and length 
Table 2. Performance indices for the Multiple Regression and Circumscribed Triangle models

\begin{tabular}{ccccc}
\hline Model & Model parameters & $\mathbf{R}^{2}$ & $\mathbf{R}^{2}$ adj & AIC \\
\hline & $\mathrm{Y}=-125.331+14.201 . \mathrm{W}+3.862 . \mathrm{L}$ & 0.96 & 0.95 & 939.14 \\
& $\mathrm{Y}=-14.9949+1.80696 . \mathrm{W}+0.4968 .(\mathrm{L} \mathrm{x} \mathrm{W})$ & 0.98 & 0.98 & 850.84 \\
$\begin{array}{c}\text { Multiple } \\
\text { Regression }\end{array}$ & $\mathrm{Y}=-75.861+6.7083 . \mathrm{W}+3.5727 . \mathrm{L}+18.1823 . \mathrm{FW}$ & 0.98 & 0.98 & 843.12 \\
& $\mathrm{Y}=-12.857+1.1678 . \mathrm{L}+11.0949 . \mathrm{FW}+0.3704 .(\mathrm{L} \mathrm{x} \mathrm{W})$ & 0.99 & 0.99 & 818.86 \\
& $\mathrm{Y}=-26.769+2.7242 . \mathrm{W}+0.77837 . \mathrm{L}+11.4251 . \mathrm{FW}+0.2924 .(\mathrm{L}$ & 0.99 & 0.99 & 814.57 \\
\hline $\begin{array}{c}\text { Circumscribed } \\
\text { Triangle }\end{array}$ & $\mathrm{x} \mathrm{W})$ & & & \\
\hline
\end{tabular}

The performance indices coefficient of determination $\left(\mathrm{R}^{2}\right)$, Pearson correlation coefficient $(\mathrm{r})$, Willmott agreement index (d) and Camargo and Sentelhas performance index (c), presented values higher than 0.89 for all leaf area determination methods. Thus, they were classified as very good (Table 3 ).

Table 3. Performance indices for leaf area determination methods

\begin{tabular}{cccccccccc}
\hline Methods & $\mathbf{R}^{2}$ & RMSE & MAE & EMAX & r & d & c & \multicolumn{2}{c}{ NSE PBIAS } \\
\hline Leaf Discs & 0.89 & 39.33 & 26.85 & 126.35 & 0.94 & 0.97 & 0.93 & 0.87 & 1.40 \\
ImageJ & 0.97 & 53.76 & 44.65 & 107.67 & 0.98 & 0.93 & 0.95 & 0.77 & -22.70 \\
Corrected ImageJ & 0.97 & 20.82 & 14.94 & 65.31 & 0.98 & 0.99 & 0.98 & 0.96 & -4.80 \\
W - WxL & 0.98 & 14.48 & 10.55 & 54.20 & 0.99 & 0.99 & 0.99 & 0.98 & 0.00 \\
W - L - FW & 0.98 & 13.81 & 10.93 & 36.71 & 0.99 & 1.00 & 0.99 & 0.98 & 0.00 \\
L - FW - WxL & 0.99 & 12.27 & 8.86 & 37.90 & 0.99 & 1.00 & 0.99 & 0.99 & 0.00 \\
W - L - FW - WxL & 0.99 & 11.91 & 8.73 & 36.29 & 0.99 & 1.00 & 0.99 & 0.98 & 0.00 \\
Circumscribed Triangle & 0.99 & 14.71 & 10.66 & 58.91 & 0.99 & 0.99 & 0.99 & 0.98 & 0.40 \\
\hline
\end{tabular}

$\mathrm{R}^{2}$ - Coefficient of determination; RMSE - mean square error, MAE - mean absolute error, EMAX - absolute maximum error, $r$-Pearson correlation coefficient $d$ - Willmott Agreement Index, c - Confidence Index, NSE - Modeling Efficiency Ratio and PBIAS - percentage bias

Regarding the observed data deviation indicators in relation to the LI-3100C, root mean square error (RMSE), mean absolute error (MAE) and absolute maximum error (EMAX) showed smaller deviations for corrected ImageJ methods, and the leaf dimension models (W WxL; W - L - FW; L - FW - WxL; W - L - FW - WxL; and circumscribed triangle), thus indicating a better relationship of methods and models. In contrast, discs and ImageJ methods without correction showed higher values of deviations (Table 3).

In turn, the modeling efficiency index (NSE) and percentage bias (PBIAS) rated the methods as very good, except for the uncorrected ImageJ method, which was good for NSE (0.7672) and unsatisfactory for PBIAS (-22.7), due to the underestimation observed (Table 3 and Figure 8B). 

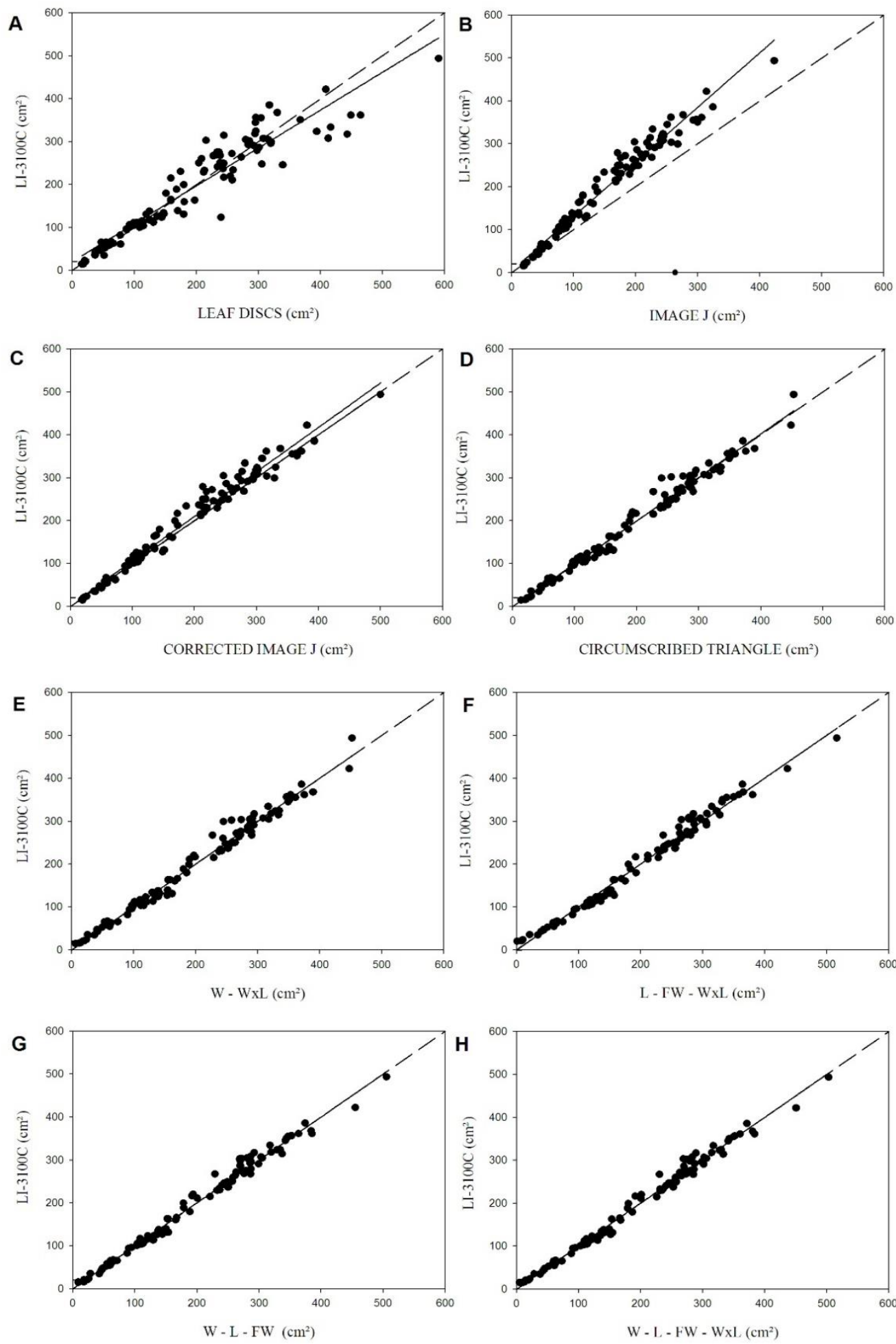

Figure 8. Relationship of reference leaf area (LI-3100C) to leaf area determined by leaf disc methods (A), Image J software (B) and corrected ImageJ software (C) and circumscribed triangle models (D) and models multiple regression model W - WxL (E), L - FW - WxL (F), L - FW - WxL (G) and W - L - FW - WxL (H) 


\section{Discussion}

The measured area by the leaf disc method is directly related to their mass. In this sense, Labbafi et al. (2017) observed for the zucchini crop that the fresh and dry leaf mass presented a high correlation with the leaf area index (LAI), which expresses the canopy leaf area per unit of soil surface. Through these relationships, the authors estimated the LAI and noticed higher coefficients of determination $\left(\mathrm{R}^{2}\right)$ between fresh and dry leaf mass in relation to other plant biometric data.

Considering the high relationship between mass and leaf area, Lavanhole et al. (2018) adopted the leaf disc method as a reference to obtain the variable for Aechmea blanchetiana (Baker) L. B. SM, by modeling from the length and width of the leaves. The obtained models were classified as adequate and presented determination coefficients $\left(\mathrm{R}^{2}\right)$ between 0.70 and 0.74 .

Obtaining the leaf area by the leaf disc method presented the highest absolute maximum error (EMAX) of 126.35 (Table 3) and the increased dispersion of the observations for leaves with larger areas in relation to the midline (Figure 8A), compared to the other methods. One of the possible sources of error of this method is related to the sampling in ribbed places (Figure 5), which allowed samples with different rib proportions. Another factor to consider is the percentage of sampled leaf area; because the leaves with the largest leaf area had a smaller sampled area, which justifies the greater dispersion of the observations (Figure 9).

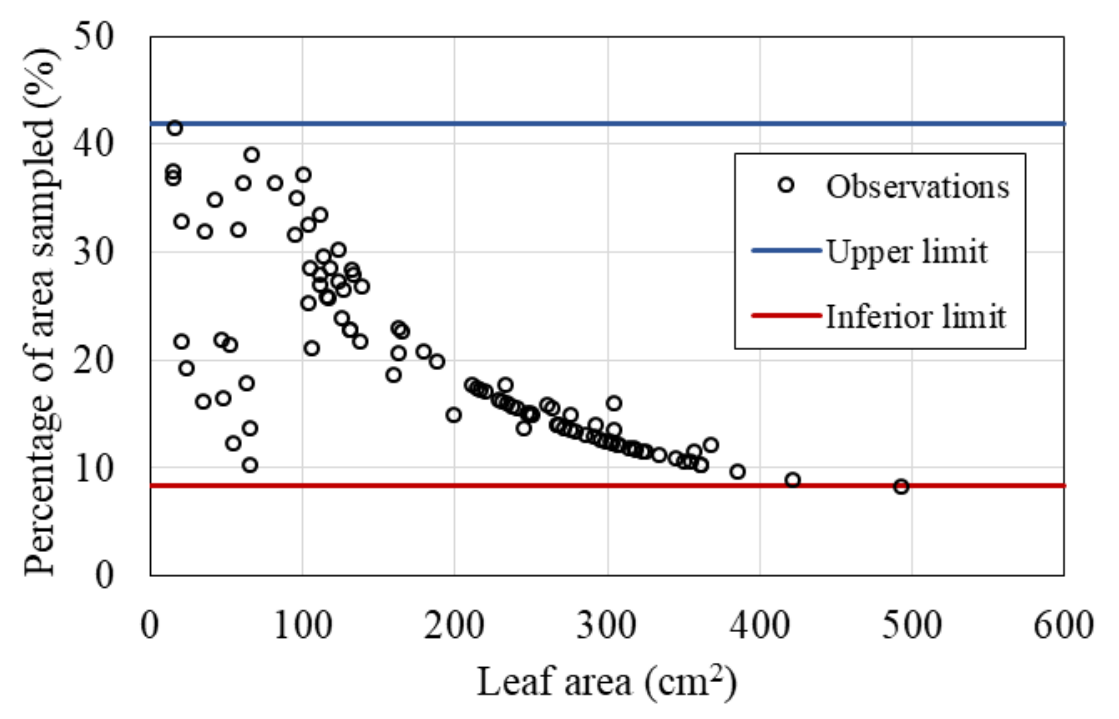

Figure 9. Percentage of area sampled in the leaf disc method as a function of leaf area

In the present study, to determine the leaf area by ImageJ, it was necessary to perform a correction because the method underestimated the area observed by the LI-3100C (Figure 8B) due to errors arising from camera lens curvature. With the correction, the NSE and PBIAS evaluation criteria were improved, which became qualified as very good. According to Rios et al. (2018), the camera lens generates distortion, especially at the edges of the captured image. Therefore, calibration with images from known areas is recommended. 
Zárate-Salazar et al. (2018), compared different software for determining the leaf area and verified that ImageJ has the necessary accuracy and precision for the research. The authors emphasize the practicality and ease of installation and handling, in addition of being a free software, with access available to any user. Additionally, Katabuchi (2015) and Santana et al. (2018) also verified that the automation of ImageJ by the $\mathrm{R}$ system with the LeafArea package proved to be a very efficient application with high precision and easy calibration in leaf area estimation, which reduces working time.

The circumscribed triangle model, which is based on the correlation between the leaf area observed by the LI-3100C and the area of a triangle, showed lower AIC value and performance indexes classified as very good (Tables 2 and 3), with the correction where the actual leaf area is larger than the triangle area. Thus, the model equation, given by $\mathrm{Y}=$ 1.09039. (W x L)/2, demonstrates that the leaf area is about $9.04 \%$ larger than the triangle area (Figure 8D).

Models that use simple relationships between width (W) and length (L) can facilitate leaf area estimation and approximate leaf areas to areas of a known geometric figure (such as the triangle or rectangle, for example). In this context, Maldaner et al. (2009) identified models to estimate sunflower leaf area (Helianthus annuus L.), among which one uses the $\mathrm{W} x \mathrm{~L}$ ratio, with an equation similar to the area of a rectangle $(\mathrm{Y}=0.7330 . \mathrm{W} \times \mathrm{L})$. Such model presented good correlation $\left(\mathrm{R}^{2}=0.97\right)$ and RMSE equal to 145.6. Cargnelutti Filho et al. (2015) also identified a good fit of the linear model based on the $\mathrm{W} x \mathrm{~L}$ ratio to estimate the leaf area of three canola hybrids (Brassica napus L.), with $\mathrm{R}^{2}$ ranging from 0.95 to 0.97 .

The coefficient of determination of the multiple regression models, using the variables of leaf width, length and mass of the zucchini leaf, ranged from 0.96 to 0.99 (Table 2), classifying the models as very good and superior to leaf area models of several other cultures. Salazar et al. (2018) used the non-destructive method to estimate the leaf area of cacao (Theobromacacao L.) using leaf length and width, obtained a coefficient of determination higher than 0.90 .

Serdar and Demirsoy (2006) also used length and width measurements to estimate the leaf area of Brazil nut (Castanea sativa) and in the adjustment of multiple regression models, reached a coefficient of determination greater than 0.89. Koubouris et al. (2018) estimated the leaf area of ten olive (Olea europaea) cultivars submitted to two water availability regimes (irrigated and rainfed). The linear equation was adjusted by the product between length and width, in which for the estimation of the irrigated olive leaf area the coefficient of determination was 0.953 and for rainfed 0.927 .

It is noteworthy that the circumscribed triangle and multiple regression models, generated in the present work, with the biometric characteristics present very good performances, but are limited to the species, and even to the studied cultivar. In contrast, the other methods may be more practically applied to studies of other cultures. 


\section{Conclusions}

The non-destructive methods ImageJ corrected and the linear regression models between the leaf dimensions and the circumscribed triangle, presented better performance to obtain the zucchini leaf area.

Prior calibration of the ImageJ method is required to estimate the most accurate leaf area.

The classic method of leaf disks presented inferior performance.

Non-destructive methods in determining leaf area facilitate in making accurate decisions in crops or in greenhouse crops, as the leaf area is directly correlated with solar interception and its effects on biomass production and yield, for example.

\section{Acknowledgement}

The authors thank the Conselho Nacional de Desenvolvimento Científico e Tecnológico (CNPq) and Coordenação de Aperfeiçoamento de Pessoal de Nivel Superior (CAPES) for providing scholarships to the authors.

\section{References}

Akaike, H. (1974). A new look at the statistical model identification. IEEE Transactions on Automatic Control, 19(6), 716-723. https://doi.org/10.1109/TAC.1974.1100705

Bianchini, C. (2013). Sistemas de manejo de solo para a produção de abobrinha de tronco (Cucurbita pepo). Paraná: Universidade Tecnológica Federal do Paraná, Programa de Pós-Graduação em Zootecnia. Dois Vizinhos, Dissertação de Mestrado.

Camargo, A. P., Sentelhas, P. C. (1997). Avaliação do desempenho de diferentes métodos de estimativa da evapotranspiração potencial no Estado de São Paulo, Brasil. Revista Brasileira de Agrometeorologia, 5(1), 89-97.

Camargo. L. S. (1981). As hortaliças e seu cultivo. Campinas: Fundação Cargill, 321p.

Cardoso, A. I. I., \& Souza Neto, I. L. (2016). Melhoramento de abóbora, abobrinha e moranga. In: Nick, C., Borèm, A. (Eds.). Melhoramento de hortaliças. Viçosa, MG: Editora UFV, p. 61-94.

Cargnelutti Filho, A., Toebe, M., Alves, B. M., Burin, C., \& Kleinpaul, J. A. (2015). Estimação da área foliar de canola por dimensões foliares. Bragantia, 74(2), 139-148. https://doi.org/10.1590/1678-4499.0388

Francisco, J. P., Diotto, A. V., Folegatti, M. V., Silva, L. D. B., \& Piedade, S. M. S. (2014). Estimativa da área foliar do abacaxizeiro cv. Vitória por meio de relações alométricas. Revista Brasileira Fruticultura, 36(2), 285-293. https://doi.org/10.1590/0100-2945-216/13

Hoagland, D., \& Arnon, D. I. (1950). The water culture method for growing plants whithout soil. California Agriculture Experimental Station, 347, 1-32.

IEA - Instituto de Economia Agrícola (20190. Valor da produção dos principais produtos da agropecuária do Estado de São Paulo. http://ciagri.iea.sp.gov.br/nia1/vp.aspx?cod_sis=15

Katabuchi, M. (2015). LeafArea: an R package for rapid digital image analysis of leaf area. Ecological Research, 30(6), 1073-1077. https://doi.org/10.1007/s11284-015-1307-x 
Koch, P. S. (1995). Análise genética de um cruzamento dialélico de abobrinha (Cucurbita pepo L.). Piracicaba, 79p. Tese (Dissertação - Mestrado) - Escola Superior de Agricultura "Luiz de Queiroz", Universidade de São Paulo.

Koubouris, G., Bouranis, D., Vogiatzis, E., Nejad, A. R., Giday, H., Tsaniklidis, G., \& Fanourakis, D. (2018). Leaf area estimation by considering leaf dimensions in olive tree. Scientia Horticulturae, 240, 440-445. https://doi.org/10.1016/j.scienta.2018.06.034

Labbafi, M., Khalaj, H., Allahdadi, I., Nadjafi, F., \& Akbari, G. A. (2017). Using models for estimation of leaf area index in Cucurbita pepo L. Journal of the Saudi Society of Agricultural Sciences, 18(1), 55-60. https://doi.org/10.1016/j.jssas.2016.12.006

Lavanhole, D. F., Oliveira, P. S., Vitória, E. L., \& Aoyama, E. M. (2018). Estimativa de área foliar por meio de relações alométricas em Aechmeablanchetiana (Baker) LB SM sob distintas condições de luminosidade. Iheringia Série Botânica, 73(3), 363-373. https://doi.org/10.21826/2446-8231201873313

Lopes, F. L., Amaro, G. B., \& Barbieri, R. L. (2017). Cultivares. In: Nick, C., Borém, A. Abóboras e morangas: do plantio à colheita. Viçosa: Editora UFV, cap. 4, p. 70-96.

Maldaner, I. C., Heldwein, A. B., Loose, L. H., Lucas, D. D. P., Guse, F. I., Possebon \& Bortoluzzi, M. (2009). Modelos de determinação não-destrutiva da área foliar em girassol. Ciência Rural, 39(5), 1356-1361. https://doi.org/10.1590/S0103-84782009000500008

Moriasi, D. N., Gitau, M. W., Pai, N., \& Daggupati, P. (2015). Hydrologic and water quality models: Performance measures and evaluation criteria. Transactions of the ASABE, 58(6), 1763-1785. https://doi.org/10.13031/trans.58.10715

Nash, J. E., \& Sutcliffe, J. V. (1970). River flow forecasting through conceptual models part I - A discussion of principles. Journal of Hydrology, 10(3), 282-290. https://doi.org/10.1016/0022-1694(70)90255-6

Rios, G. F. A., Ribeiro, F. C., Mata, J. A., Silva Júnior, J. J., \& Souza Oliveira, G. (2018). Mensuração fenológica e fotogramétrica foliar com lasers e câmara digital. Revista Brasileira de Agricultura Irrigada, 12(2), 2487-2499. https://doi.org/10.7127/rbai.v12n200765

Salazar, J. C. S., Melgarejo, L. M., Bautista, E. H. D., Di Rienzo, J. A., \& Casanoves, F. (2018). Non-destructive estimation of the leaf weight and leaf area in cacao

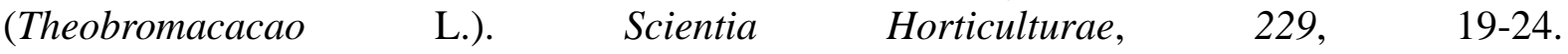
https://doi.org/10.1016/j.scienta.2017.10.034

Santana, H. A., Rezende, B. R., Santos, W. V. D., \& Silva, A. R. D. (2018). Models for prediction of individual leaf área of forage legumes. Revista Ceres, 65(2), 204-209. https://doi.org/10.1590/0034-737x201865020013

Schindelin, J., Rueden, C. T., Hiner, M. C., \& Eliceiri, K. W. (2015). The ImageJ ecosystem: An open platform for biomedical image analysis. Molecular Reproduction and Development, 82(7-8), 518-529. https://doi.org/10.1002/mrd.22489

Schwab, N. T., Streck, N. A., Rehbein, A., Ribeiro, B. S. M. R., Ulhmann, L. O., Langner, J. A., \& Becker, C. C. (2014). Dimensões lineares da folha e seu uso na determinação do perfil vertical foliar gladíolo. Bragantia, 73(2), 97-105. https://doi.org/10.1590/brag.2014.014

Serdar, Ü., \& Demirsoy, H. (2006). Non-destructive leaf area estimation in chestnut. Scientia Horticulturae, 108(2), 227-230. https://doi.org/10.1016/j.scienta.2006.01.025 


\section{Macrothink}

Journal of Agricultural Studies

ISSN 2166-0379 2020, Vol. 8, No. 3

Willmott, C. J. (1981). On the validation of models. Physical geography, 2(2), 184-194. https://doi.org/10.1080/02723646.1981.10642213

Yapo, P. O., Gupta, H. V., \& Sorooshian, S. (1996). Automatic calibration of conceptual rainfall-runoff models: sensitivity to calibration data. Journal of Hydrology, 181(4), 23-48. https://doi.org/10.1016/0022-1694(95)02918-4

Zárate-Salazar, J. R., Santos, M. N., Santos, J. N. B., \& Isla, F. L. (2018). Comparação de softwares de análise de imagem para a determinação da área foliar. Revista Brasileira de Meio Ambiente, 3(1),

3(1), 024-032.

https://revistabrasileirademeioambiente.com/index.php/RVBMA/article/view/44/83

\section{Copyright Disclaimer}

Copyright for this article is retained by the author(s), with first publication rights granted to the journal.

This is an open-access article distributed under the terms and conditions of the Creative Commons Attribution license (http://creativecommons.org/licenses/by/4.0/). 